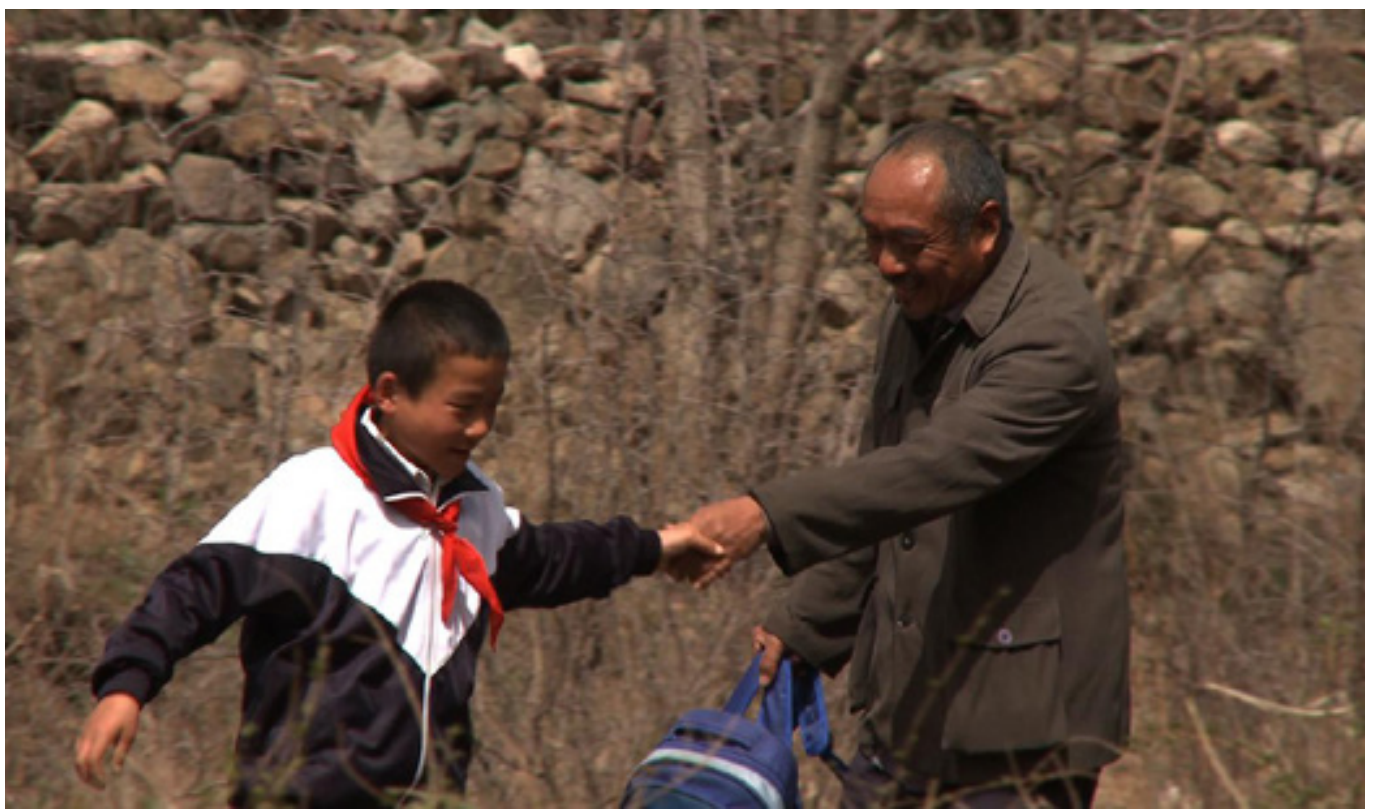

\title{
Crime and Punishment on a Chinese Border
}

Still from Zhao Liang's documentary Crime and Punishment. (DGenerate Films, 2007).

Suzanne Scoggins

Zhao Liang's 2007 documentary Crime and Punishment details the emergence of a local police state in a small Chinese town on the border with North Korea. The film follows national border officers who have been called in to take over the town's policing duties, and the ways in which they interact with local people. As the film unfolds, one incident after another, viewers are drawn into a world of policing which is slow, tiresome, petty, and punctuated with violence. $\checkmark$ hao Liang's documentary Crime and Punishment (zui yu fa) provides a rare, candid window into the tedium of law enforcement in China. Filmed in a poor district of Dandong, a city along the Yalu River on China's border with North Korea, it follows a group of border officers charged with taking over law enforcement duties at the local police station. As the camera lingers long past the point of comfort on details such as the militarystyle folding of bed sheets or a scrap collector's pained face, the viewer is drawn into a world of policing where law enforcement is slow, tiresome, petty, and punctuated with violence. 


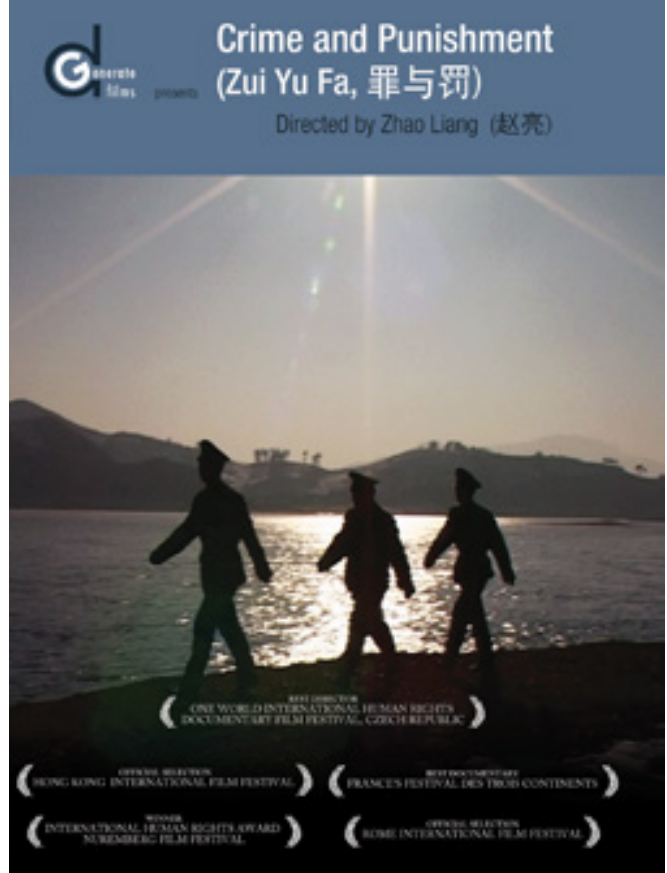

Crime and

Punishment,

(DGenerate Films.

2007)

\section{Power and Powerlessness}

In the film, the border police are initially praised for their service at a station in the impoverished Zhen'an district of Dandong, having set up regular patrols and assumed a variety of duties that typically fall on the shoulders of the local people's police. These officers are attached to the army, not the Ministry of Public Security, and their presence in a largely rural area such as this is relatively rare. Unfortunately, the film does not capture the more serious security concerns that we can only guess led to this arrangement. We are instead treated to a parade of petty criminal cases that showcase the desperation and powerlessness of the residents who come into contact with the border police.
From berating a mentally ill man for making a false call about a dead body that was actually a pile of blankets, to the busting up of a mahjong game, the motley crew of officers lumbers from one small case to the next. Viewers will likely feel sympathy for the plight of the three men who get caught trying to make money off illegally harvested trees in advance of the Chinese New Year or the deaf man detained for pickpocketing a cell phone. In both cases, the police exercise casual violence on camerasmacking the suspects around in order to elicit information and a much-prized confession. In China, a case is not solved until the perpetrator has confessed-a fact acknowledged by one of the officers on camera after his colleague hauls away a suspect to an undisclosed area where a confession will presumably be coerced. In rare cases, however, the need for a signed confession can work in a suspect's favour. The deaf cell phone thief is ultimately released for lack of evidence because the officers are unable to take his statement.

\section{Violence and Petty Harassment}

Zhao weaves the theme of violence though many of the film's interactions, and rightly so, given the coercive duties that frontline agents like these are charged with performing on behalf of the state. Unsurprisingly, the more violent acts of interrogation are committed off camera. Since stations have long been required to film interrogations, removing suspects from the interrogation room, away from the cameras, in order to grease the wheels is a widespread practice, and in interviews, officers have acknowledged that they know just where to go and just where to hit in order to avoid proof that they used excessive force (Scoggins 2018). Naturally, most if not all officers are in on this game, and in one 'good cop, bad cop' scene we see the good cop grin to the camera as he tells the bad cop-who is taking the suspect awayto go easy on him. 


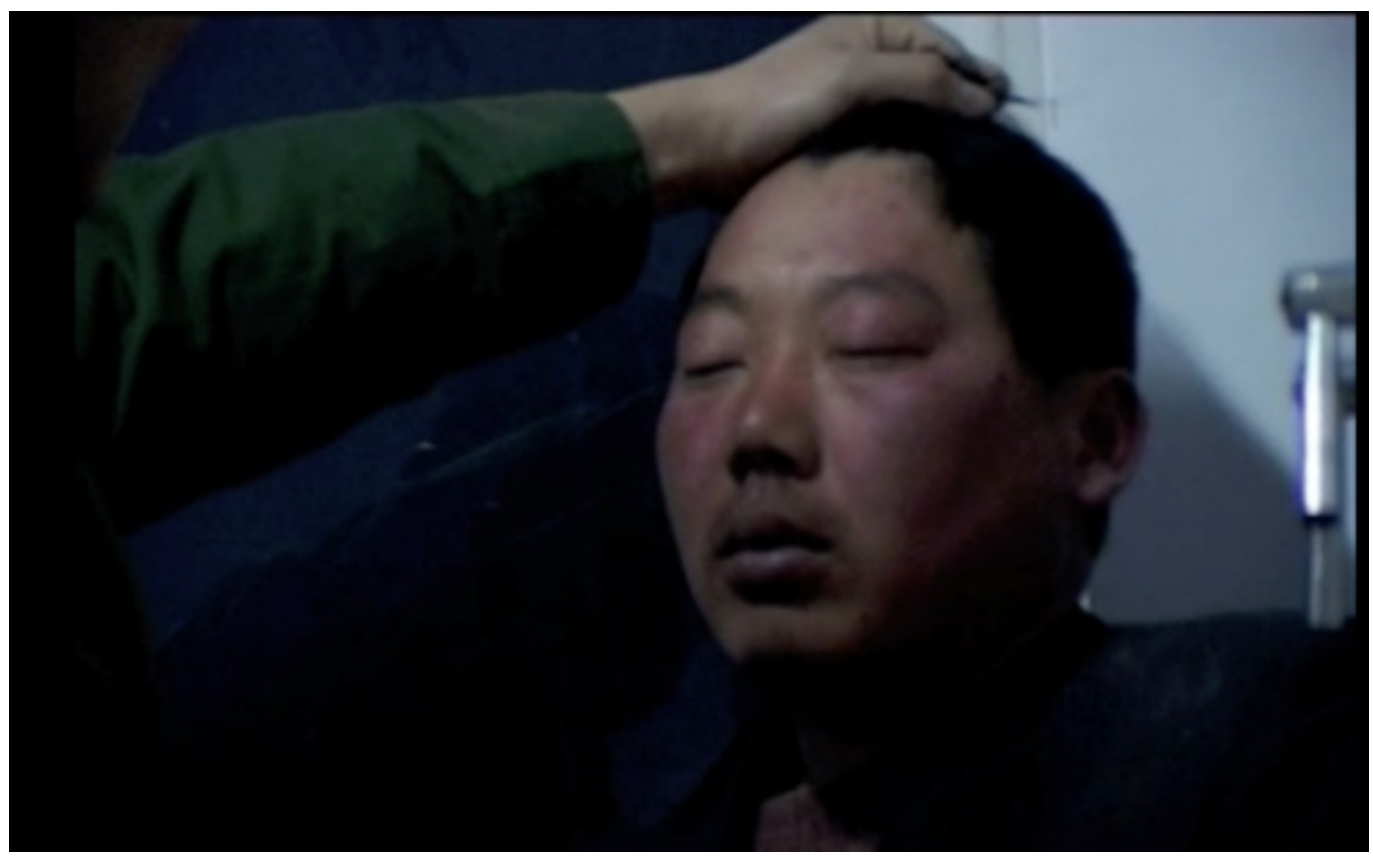

Two cops beating a suspect's bruised face. Still from Zhao Liang's documentary Crime and Punishment.

The oddly swollen faces and general lethargy of the suspects shown on camera immediately following such incidents are the physical signs of officer brutality. Yet we also see evidence that the power of the border police is not wholly unchecked. When one lumber thief is hauled back to his house to show where he illegally felled the trees, his wife sees his puffy face and begins shouting at the border officers. She follows them down the road, telling them they can enforce the law and levy fines but cannot go around beating people, especially right before the New Year. Shortly thereafter, we learn that the men were able to keep the lumber and pay a significantly reduced fine because the supervisors of the border officers feared repercussions.

Pettiness is also a theme that runs through the film. In no place is this more evident than the flashes of anger displayed by the border officers after they overhear the scrap collector's son curse the police in a phone conversation. Of all the town residents shown throughout the film, the scrap collector is most memorable. Hauling the elderly man in with his donkey and cart in order to berate him for lack of a permit seems like petty harassment enough, but the frustration and vitriol that erupt in the wake of the overheard phone conversation-replete with threats to keep his cart and kill his donkey-are difficult to watch. Rather than policing serious crimes, we see the border police and their bruised egos on full display as they harangue poor and vulnerable residents for very little in return. The scrap collector is finally let go with a warning, and he hastily drives his cart around the corner and out of sight, presumably to resume his work. 


\section{The Banality of Everyday Life}

Those who make it past the first hour of an undeniably slow film will be rewarded with the promise of a murder case. As officers post notices around town, clean guns, and set up checkpoints, viewers may understandably hope that the real action is about to begin. Instead, we are treated to shots of a few normal traffic stops, a driver whose defiant refusal to stop may remind China-watchers of other well-known incidents (Williams 2017), and the interception of the film's hapless lumber thieves. Because the latter two are shown back to back, the viewer is led to believe that the officers-exasperated with their inability to make progress on the case and angry at the man who refused to stop-take their frustrations out on the lumber thieves. This may indeed have been the case, but in telling their story, we miss out on a chance to see how they resolve the murder. This is a shame since the handling of murder cases in China has sparked suspicion that the government's claim of having one of the lowest murder rates in the world is fabricated (Li 2017; The Economist 2013).

Those looking for a window into the everyday life of law enforcement officers in China will not be disappointed. An early scene captures a conversation about hair dye and hair loss. One officer confides that his hair problems began after a particularly bad summer with the coast guard. He blames it on late nights, insomnia, and stress-issues that have been well documented by scholars (Scoggins and O'Brien 2016; Wang 2015; Wang, et. al 2015)-and we are told that Apollo shampoo will help. As the border officers tramp through snow while patrolling isolated areas or sleep with their faces crushed into office chairs, viewers should take heart that the film's slow pace mirrors the realities of ground-level work. While this does not necessarily make for riveting viewing, its authenticity makes it a fair trade.

\section{Blurred Boundaries}

The film-released in 2007-feels especially relevant today in light of the ramping up of police presence in Xinjiang. Reports of reeducation camps and increases in government spending leave us with many questions and few glimpses into what interactions between security agents and residents actually look like on the ground (Zenz 2018a and 2018b). Although set in a very different context, the world captured by Zhao gives us remarkable insight into how law enforcement practices can blur boundaries between right and wrong, violence and mercy. Zhao peppers his scenes with shots of the officers cursorily taking care of two dogs, leaving us to wonder if the dogs represent the public or the officers themselves. The final scenes present an answer. As one officer and one dog are summarily dismissed by way of pink slip and knife to the stomach, respectively, we see how some agents of the state get caught in the gears of a force much stronger than they are. 